\title{
Manfaat Prasasti Bagi Penulisan Sejarah Lokal
}

\section{Djoko Dwiyanto}

Keywords: interpretation, methods, theory, inscription, java

\section{How to Cite:}

Dwiyanto, D. (1998). Manfaat Prasasti Bagi Penulisan Sejarah Lokal. Berkala Arkeologi, 18(1), 1-6. https:// doi.org/10.30883/jba.v18i1.771

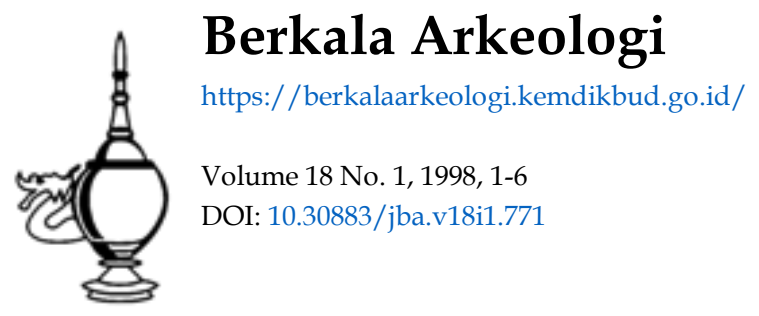

\section{(c) (i) (3)}

This work is licensed under a Creative Commons Attribution-NonCommercial-ShareAlike 4.0 International License. 


\title{
MANFAAT PRASASTI BAGI PENULISAN SEJARAH LOKAL
}

\author{
Djoko Dwiyanto \\ (Jurusan Arkeologi Fakultas Sastra - UGM)
}

\section{Pengantar}

Secara umum telah diketahui bahwa penulisan sejarah adalah proses transformasi dari sejarah yang objektif menjadi sejarah subjektif melalui jalur dan proses rekonstruksi (membuat konstruk). Sejarah dalam arti objektif mengacu kepada kejadian (events) atau proses sejarah dalam aktualitasnya. Kejadian itu hanya sekali terjadi dan tidak dapat diulang atau terulang kembali. Sejarah dalam arti subjektif, yaitu suatu kejadian yang sudah disajikan melalui pikiran seseorang, sehingga mengandung unsur-unsur dari si subjek. Faktor-faktor yang mempengaruhi subjektivitas itu terdiri atas subjektivitas itu terdiri atas subjektivitas pribadi yang muncul dari jamannya (Zeitgebunenheid - Sartono Kartodirdjo, 1992:16 dan 62).

Sebagai sebuah bangunan pariwisata yang pernah terjadi, penulisan sejarah memerlukan berbagai bahan agar bangunan itu dapat menggambarkan apa yang sebenarnya terjadi. Sebagai sebuah lukisan sejarah dapat diketahui objeknya, teknik penggarapannya, pandangannya, dan gayanya. Namun demikian hampir dipastikan tidak mungkiin seseorang dapat mengamati dan mengikuti secara total suatu peristiwa yang pernah terjadi. Oleh karena itu kemudian muncul beberapa macam tipe sejarah, yaitu sejarah tentang kejadian-kejadian, sejarah konjunktural, dan sejarah jangka panjang atau struktural.

Penulisan sejarah di Indonesia berkembang dengan pesat sejalan dengan model pendekatan baru yang melibatkan ilmu-ilmu sosial untuk memberikan eksplanasi terhadap peristiwa sejarah yang menjadi objek penelitian. Perkembangan model ini memberikan peluang munculnya karya-karya penulisan sejarah dengan tema-tema pergerakan sosial, perubahan sosial, pemberontakan, serta kasus-kasus hubungan sosial lainnya. Sebagai konsekuensi logis dari perkembangan ini adalah berkurangnya karya-karya tentang pemerintahan negara dan kalangan istana, tetapi menyuburkan tumbuhnya karya tentang peristiwa hubungan sosial dalam lingkup spasial yang lebih terbatas. Salah satu dari aspek kajian sejarah yang berkembang cukup pesat adalah penulisan sejarah lokal. Kesadaran baru terhadap penulisan sejarah lokal memberikan kesempatan terhadap penjelasan sejarah secara struktural dalam pola-pola sosial dan dinamika yang terdapat dalam lokalitas yang sedang dibicarakan. Ruang lingkup scjarah lokal, seperti tersirat dalam tema pokok yang dibicarakan dalam Seminar Sejarah Lokal (1984), antara lain adalah dinamika masyarakat pedesaan, pendidikan 
sebagai faktor dinamisasi dan integrasi sosial, interaksi antar suku bangsa dalam masyarakat majemuk, revolusi nasional di tingkat lokal, dan biografi tokoh lokal.

Penulisan sejarah Indonesia kuna dalam berbagai keterbatasan yang dimiliki dapat disebut sebagai sejarah tentang kejadian-kejadian (I'histoire événementielle) dan sejarah jangka panjang atau struktural (Ibid : 81). Hal ini disebabkan oleh terbatasnya sumber bahan penulisan sejarah, baik secara kualitatif maupun kuantitatif. Salah satu sumber penulisan sejarah kuna yang paling utama adalah prasasti. Prasasti adalah sebuah piagam yang dikeluarkan oleh penguasa kerajaan untuk kepentingan penetapan suatu daerah menjadi sima, maka banyak prasasti yang tidak memuat latar belakang peristiwa yang terjadi pada masa itu. Selain itu karena prasasti dikeluarkan oleh penguasa kerajaan yang wilayah pemerintahannya menunjuk pada lokalitas tertentu, maka dengan keterbatasan itu justru dapat dikaji secara mendalam berbagai aspek kehidupan dalam skala mikro.

\section{Kegunaan dan Penggunaan Prasasti}

Salah satu kajian dalam bidang Arkeologi Indonesia adalah sejarah (kuna), yang meskipun secara kronologis munculnya lebih dahulu, tetapi secara departemental menjadi bagian dari arkeologi. Hubungkait antara arkeologi dan sejarah telah banyak dikaji baik secara institusional maupun secara substansial (Nugroho Notosusanto, 1965: I dan Boechari, 1978:4). Secara institusional kajian arkeologi di Indonesia dimulai dengan perhatian dan kajian terhadap peristiwa sejarah yang ditunjukkan oleh bukti-bukti material, misalnya candi, arca, dan prasasti. Dengan kata lain bukti-bukti (sumber) sejarah dalam periode tertentu dapat dilacak tidak hanya berdasarkan bukti testual, tetapi juga yang bersifat artefaktual. Secara substansial diketahui bahwa arkeologi sebagai ilmu yang berupaya untuk merekonstruksi peristiwa masa lampau melalui tinggalan budaya materi, pada hakikatnya sama dengan proses penulisan sejarah.

Di antara berbagai sumber penulisan sejarah kuna, prasasti menduduki peringkat teratas, karena prasasti ditulis pada masa yang bersamaan dengan peristiwanya. Meskipun demikian tidak banyak yang dapat diungkap dari prasasti dan sebaliknya prasasti tidak dapat memberikan informasi yang utuh atau menyeluruh tentang sesuatu aspek. Oleh karena itu penggunaan prasasti sebagai sumber sejarah harus melalui prosedur yang disebut penafsiran (interpretasi).

Seperti halnya pokok pembicaraan tentang kebudayaan pada umumnya, lebih-lebih pokok bahasan tentang prasasti sangat sedikit porsinya dalam wacana akademik. Hal ini disebabkan oleh dua arah pembicaraan, intern pemerhati dan dari luar/eksternal. Dari dalam kurang upaya untuk mempresentasikan kepada publik, tetapi masih 
terbatas pada lingkungan intern. Dari pihak luar kurang apresiatif, karena pemahamannya sulit, masa bodoh, atau tidak memberikan keuntungan sehingga tidak ada kepentingannya. Secara objektif sebenarnya prasasti mempunyai ciri-ciri dan karakteristik sesuai dengan perkembangannya, mulai dari pemilihan media, jenis tulisan/aksara, bahasa yang digunakan, sampai dengan struktur dan susunannya. Adakalanya prasasti-prasasti yang mempunyai karakteristik sama dapat membantu penentuan kronologinya, jika di dalamnya tidak memuat unsur penanggalan (Casparis, $1978: 5)$.

Secara umum struktur prasasti, terutama yang berbahasa Jawa Kuna, terdiri atas unsur penanggalan, pemujaan terhadap dewa tertentu, peristiwa yang diperingati dalam prasasti, alasan dan tujuan penetapan sima, keterangan luas tanah, keterangan tentang pembelian/ganti rugi tanah (bila ada), persembahan kepada yang memimpin upacara ("... wyawastha ning manusuk sîma ..."), daftar saji-sajian, pemberian pasêk-pasêk kepada para pejabat yang hadir, upacara penetapan, tontonan (kadang-kadang), dan pejabat yang diperintahkan melaksanakan pematokan/pembatasan tanah. Oleh karena itu dengan melalui penafsiran terhadap kalimat-kalimat yang tertulis dalam prasasti, rekonstruksi peristiwa masa lampau (sejarah) dapat ditulis mencakup ruang lingkup yang sangat luas. Aspek politik dapat diketahui melalui struktur birokrasi pemerintahan kerajaan seperti disebut pada bagian pejabat yang menerima pasêkpasêk, sehingga dapat ditafsirkan terdapatnya susunan pemerintahan dan mekanismenya. Aspek ekonomi dapat dikutip berdasarkan barang-barang yang disebut baik sebagai kelengkapan upacara maupun sebagai komoditas yang diperjual belikan. Selain itu perekonomian juga tampak dari mekanisme distribusi dan redistribusi melalui proses hubungan sosial yang tergambar dalam kalimat prasasti, misalnya pihak dan jumlah personal yang hadir dalam sebuah penetapan sîma, mulai dari pejabat kerajaan, pejabat desa sekelilingnya, sampai warga masyarakat kebanyakan baik laki-laki maupun perempuan. Demikian pula aspek budaya sangat nyata tampak dari sistem religi yang berlaku, jenis-jenis upacara berikut pirantinya, dan jenis tontonan yang menyertai penetapan sîma itu.

Berdasarkan kenyataan bahwa dari kalimat-kalimat prasasti dapat digunakan sebagai sumber penulisan sejarah, maka sudah barang tentu berbagai tipe penulisan sejarah juga dapat dilakukan berdasarkan sumber prasasti. Salah satu di antara tipe penulisan sejarah yang dapat ditulis berdasarkan prasasti adalah sejarah struktural, khususnya sejarah lokal. Mengingat prasasti pada umumnya menyebut lokalitas tertentu, maka rekonstruksi sejarah yang ditulis berdasarkan prasasti (beberapa prasasti) juga dapat disebut sebagai sejarah lokal.

Prasasti selain dapat digunakan sebagai sumber penulisan scjarah, secara praktis juga dapat digunakan sebagai tanda awal dimulainya suatu aktivitas kolektif. Oleh sebab itu sangat banyak karya-karya penulisan yang digunakan sebagai penetapan harijadi 
suatu daerah, didasarkan atas sumber prasasti (Djoko Dwiyanto, 1994). Di dalam konteks penulisan sejarah Indonesia kuna prasasti juga dapat digunakan sebagai bahan evaluasi penulisan sejarah scbelumnya dan rekonstruksi kembali sebuah hasil penulisan sejarah, mengingat peluang ditemukannya prasasti-prasasti baru sangat terbuka lebar sejalan dengan aktivitas penelitian arkeologi pada umumnya.

\section{Sejarah Lokal Berdasarkan Sumber Prasasti}

Bagaimanapun diakui di kalangan sejarawan bahwa kesadaran baru terhadap penulisan sejarah lokal ternyata dapat memberikan gambaran betapa kaya sebenarnya sejarah lokal di Indonesia (Kuntowidjojo, 1994:121). Meskipun manfaatnya sangat besar dalam konteks penyusunan sejarah Indoensia, tetapi upaya penulisan sejarah lokal masih menemukan berbagai kendala, terutama ketersediaan sumber. Sumber sejarah yang memadai diperlukan, karena dalam penulisan sejarah lokal bersifat mikro, sehingga menuntut metodologi khusus. Penulisan sejarah jenis ini harus mempunyai kerangka konseptual yang cukup halus agar dapat dilakukan analisis yang tajam, sehingga pola-pola mikro dapat diekstrapolasikan (Sartono, 1992: 74)

Sejarah lokal yang sama tidak menarik perhatian, dapat bermakna jika dari lokalitas itu dapat dihubungkan dengan konteks makro yang mencakup generalisasi. Sebagai contoh misalnya kasus lokal terdapat kecenderungan yang dapat mencerminkan atau merepresentasikan gejala umum tingkat nasional, antara lain dalam proses inovasi atau transformasi. Oleh karena itu suatu sejarah lokal baru memberikan makna jika digunakan pendekatan struktural, misalnya struktur kekuasaan, struktur sosial, dan struktur agraris. Pendekatan struktural diharapkan dapat menempatkan peristiwa unik ke dalam kerangka konseptual, sehingga dapat disusun generalisasi.

Salah satu ciri yang dimiliki oleh suatu penulisan sejarah lokal adalah adanya semangat interdisipliner, sehingga dapat mendorong kesadaran dalam penggunaan teori dan konsep-konsep ilmu-ilmu sosial. Penulisan sejarah dengan pendekatan ilmuilmu sosial ini sanggup menjelaskan sejarah secara struktural dalam pola-pola sosial dan dinamika yang terdapat pada lokalitas yang dibicarakan. Di dalam konteks sejarah kuna di Indonesia, yang sangat miskin sumber baik kualitas maupun kuantitasnya, aplikasi teori ilmu-ilmu sosial dapat berguna untuk mengevaluasi cara analisis dan eksplanasi yang pernah dilakukan (Djoko Dwiyanto, 1991:14).

Berdasarkan asumsi di atas, maka prasasti sebagai sumber penulisan sejarah (kuna) dapat memberikan kontribusi terhadap penulisan sejarah lokal. Historiografi yang ditulis berdasarkan prasasti pada umumnya berisi tentang lokalitas tertentu yang dikendalikan dengan dimensi spasial dan temporal tertentu pula. Secara tidak langsung penilaian terhadap karya-karya penulisan sejarah yang digunakan sebagai 
latar belakang atau dasar penetapan harijadi suatu daerah merupakan karya sejarah lokal (Djoko Dwiyanto, 1994). Meskipun secara metodologis belum cukup memadai untuk disebut sebagai karya sejarah lokal yang penuh dengan pernik-pernik halus teori dan konsep ilmu sosial serta analisis yang tajam, tanpa disadari menjadi titik tolak rintisan ke arah penulisan sejarah lokal. Karya-karya M.M. Soekarto Kartoatmodjo seperti Harijadi Kadiri, Harijadi Ngawi, Harijadi Magelang, Harijadi Sumenep, Harijadi Banyumas, Harijadi Lumajang, Harijadi Cilacap dapat dikembangkan menjadi sebuah karya sejarah lokal yang bermakna bagi sejarah nasional. Demikian pula karya Tim Jurusan Sejarah Fakultas Sastra UGM, seperti Harijadi Jepara, Harijadi Kendal, Harijadi Kudus, Harijadi Pemalang, Harijadi, dan Harijadi Purworejo yang dimensi temporalnya lebih muda. sehingga tidak didasarkan atas sumber prasasti dapat diperluas dimulai dari masa yang paling tia, sejauh dapat ditemukan kembali sumbernya. Karya lain yang juga telah merintis terwujudnya karya penulisan sejarah lokal adalah penelusuran sejarah dan harijadi Kabupaten Kebumen dan sejarah Kabupaten Purbalingga (Djoko Dwiyanto, 1989 dan 1996), yang selain berisi inventarisasi dan deskripsi sumber sejarah lokal juga berisi biografi tokoh lokal. Dengan keterlibatan teori dan konsep ilmu-ilmu sosial serta ketajaman analisis diharapkan akan segera terwujud penulisan sejarah lokal seperti yang diharapkan.

Secara praktis manfaat yang diperoleh dari hasil penelitian dan penulisan sejarah lokal dapat memberikan implikasi untuk memahami karakteristik daerah tertentu. Di dalam konteks pembangunan daerah sangat bermanfaat dalam rangka pengambilan keputusan terhadap arah pembangunan masyarakatnya.

\section{Penutup}

Secara jujur harus diakui bahwa apresiasi masyarakat terhadap prasasti pada khususnya, sejarah pada umumnya belum menunjukkan hasil yang menggembirakan. Di dalam lingkup penelitian arkeologi sendiri (masa Indonesia Klasik) masih terdapat banyak data arkeologis dan epigrafis yang belum dianalisis secara tuntas (Boechari, 1978 : 14). Sementara dalam penelitian dan penulisan sejarah lokal masih enggan mclibatkan sumber data prasasti sebagai bahan analisis yang melibatkan dimensi waktu lebih panjang. Suatu kasus menarik pantas diutarakan sebagai gambaran aspirasi masyarakat, sekaligus koreksi terhadap bentuk pengabdian yang aspiratif, yaitu penulisań sejarah sebagai penetapan harijadi Purworejo. Hasil pengkajian terhadap sumber-sumber sejarah yang ada membuahkan kesimpulan bahan penetapan harijadi yang menunjuk dimensi waktu sejaman dengan pembagian Kerajaan Mataram/palihan nagari (13 Februari 1755) dan sekitar Perang Diponegoro (7 Januari 1928), tetapi ternyata aspirasi masyarakat menginginkan masa yang lebih tua sebagai tanda awal dimulainya keberadaan Kabupaten Purworejo (periksa : Polemik di sekitar Harijadi Purworejo di Harian Kedaulatan Rakyat tahun 1993). 
Berdasarkan kenyataan bahwa sejarah lokal menunjukkan kekayaan potensi sejarah daerah-daerah di Indonesia, sangat aspiratif untuk membangun rasa kebanggaan (sense of pride), dan prasasti sangat berpotensi dalam memberikan kontribusi terhadap penulisan sejarah lokal, maka sudah saatnya penelitian dan penulisan sejarah lokal dikembangkan sesuai dengan proporsinya. Pilihan-pilihan tema tentang sejarah lokal dapat mencakup dinamika masyarakat lokal, pertumbuhan kota meliputi demografi tokoh lokal, pertumbuhan kota meliputi demografi, urbanisasi, ekonomi. dan antrologogi. serta biografi tokoh lokal.

\section{KEPUSTAKAAN}

Boechari. 1978. Bahan Kajian Arkeologi untuk Pengajaran Sejarah. Majalah Arkeologi Th. It No. I. September 1978. Him. 3 -- 26.

Casparis. 1.G. de. 1978. Indonesian Chronology. LeidenIKoln : E.t. Brill.

Dwiyanto, Djoko, dkk., 1989. Penulusuran Sejarah dan Harijadi Kabupaten Kebumen. Tidak diterbitkan.

Dwiyanto, Djoko, 1993. Pendekatan tlmu Sosial dalam Analisis Sumber Tertulis Masa Klasik. Artetak.

Dwiyanto, D. (1994). Mantaat Sumber Data Arkeologi (Epigrati) Sebagai Acuan Penehusuran Harijadi Siuatu Daerah. Berkala Arkeologi, 14(2i), 6-9. hitps:ll doi.org/10.30883ljba.v14i2.633

Dwiyanto, Djoko, 1997. Sejarah Lahirnya Kabupaten Purbalingga, Pemda Tk. II Kabupaten Purbalingga dan LPM-UGM.

Kuntowijoyo. 1994. Metodologi Sejarah. Yogyakarta: PT Tiara Wacana Yogya.

Kuntowijoyo:1995. Pengantar Ilmu Sajarah. Yogyakarta : Yayasan Bentara Budaya.

Nugroho Notosusanto. 1965. Hubungan antara Sajarah dan Arkeologi MISI. HIm.1-8

Sartono Kartodirdjo. 1992. Pendekatan Ilmu Sosial dalam Metodologi Sajarah. takarta : PT Gramedia Pustaka Utama. 